Dept. of Animal Production,

Faculty of Agriculture, Assiut University, Egypt.

\title{
GROWING FARAFRA AND CHIOS LAMBS FED RATIONS CONTAINING VARIOUS HAY LEVELS 1- FATTENING PERFORMANCE
}

(With 4 Tables and 2 Figures)

\author{
By \\ M.N. ABD EL ATI; H. HAMDON*; \\ FATEN F. ABOU AMMO**; M. ZENHOM** \\ and $F$. ALLAM, \\ *Faculty of Agriculture, Sohag University, \\ * Animal Production Research Institute, Giza, \\ (Received at 13/3/2008)
}

تغذية حملان الفرافرة والكيوس النامية على علائق تحتوى على مستويات

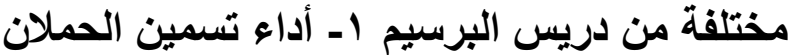

محد نصرت عبد العاطى ، حاتم حدون ، فاتن فهمى أبو عمو ، محد زينهم

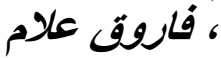

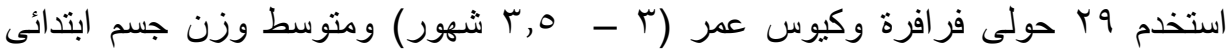

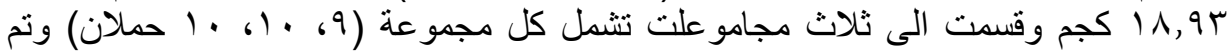

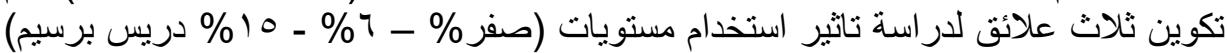

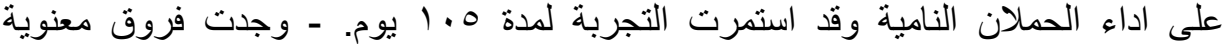

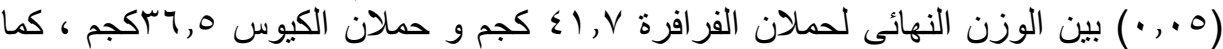

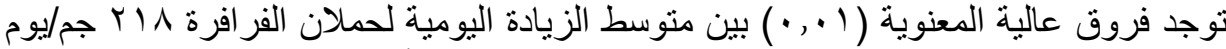

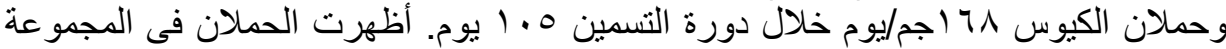

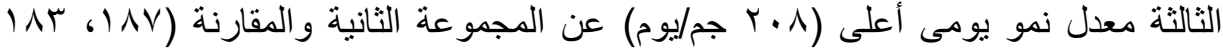

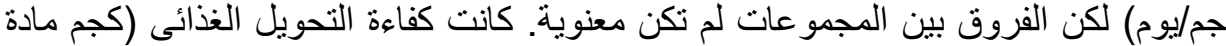

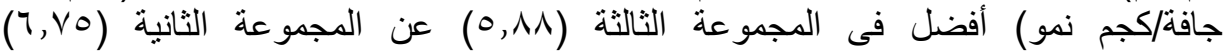

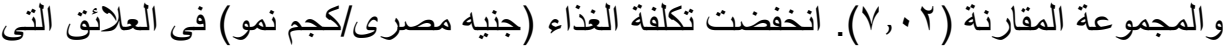

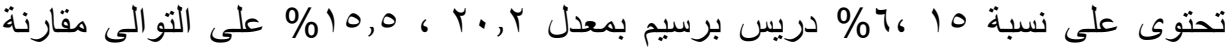

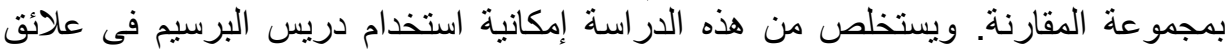

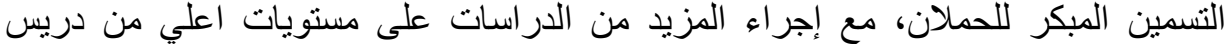
البرسيم و اثر ذلك على اداء الحملان.

\section{SUMMARY}


Twenty nine Farafra and Chios ram lambs 3 - 3.5-months-old averaging $18.93 \mathrm{~kg}$ were randomly assigned to three groups $(9,10$ and 10 lambs) that fed $0 \%, 6 \%$ and $15 \%$ hay substituted the ration barley grains. Average body weight of Farafra eighteen lambs were 25.71, 31.84, 39.06 and $41.76 \mathrm{~kg}$, at 18,22, 26, 29 weeks of age and for Chios eleven lambs were 24.43, 29.23, 35.24 and $36.57 \mathrm{~kg}$, respectively. Differences between body weights were significant $(\mathrm{P}<0.05)$. Lambs received $15 \%$ hay containing diet, had the highest body weight, total gain, and average daily gain, moreover, $15 \%$ hay group had higher average daily gain being $208 \mathrm{~g} / \mathrm{d}$ than other groups. Average total daily gains were 218 $\mathrm{g} /$ day for Farafra lambs and $168 \mathrm{~g} /$ day for Chios lambs. Lambs received 6 or $15 \%$ hay rations consumed less DM by 5.8 and $6.9 \%$, respectively, compared with the control. Highest values of feed efficiency were for group $15 \%$ hay $(5.88 \mathrm{DM})$, while the lowest efficiency value was for the control group (7.02 DM). Feed cost per $\mathrm{kg}$ gain when using diets containing hay was reduced by about 15.5 and $20.2 \%$ for group $6 \%$ hay and group $15 \%$ hay, respectively. In conclusion, the use of concentrate diets with alfalfa hay level for early fattening did improve growth performance.

Key words: Chios, Farafra, growing lambs, growth.

\section{INTRODUCTION}

In Egypt, fattening process depends on supplementary feeding rather than grazing. This is because neither grazing nor cultivated areas permissible to animals, is enough to cover even the maintenance requirements of livestock population. These circumstances render the possibility to increase livestock population to a rather unfeasible process. Also, towards better concentrates utilization in feeding sheep and economic optimization of production per animal unit (Shehata, 1997). Ponnampalam et al. (2004) found that it is better to feed hay beside grains to reduce the risk of acidosis in fattening lambs. It was of interest to examine whether Farafra or Chios ram lambs exhibit better performance by using levels of Clover (alfalafa) hay for early fattening.

\section{MATERIALS and METHODS}

The present study was carried out at Mallawi Animal Production Research Station, belonging to Animal Production Research Institute, Agriculture Research Center, Ministry of Agriculture. Twenty nine 
growing Chios $(n=11)$ and Farafra $(n=18)$ ram lambs 3 - 3.5 months of age, were randomly divided into three groups $(9,10$ and 10 lambs, respectively). Barley grains were substituted with $0 \%, 6 \%$ and $15 \%$ hay. Average initial body weight was $18.93 \mathrm{~kg}$. All animals were vaccinated using Covaxin ${ }^{8} 8$ and Ivomec $®$ before the start of fattening experiment. The rations were offered ad libitum, using specific feeder, which prevents the feed contamination by lambs feet, besides controlling the release of feed trough, it guarantees clean and fresh feed all the time. Fresh water was available at all times. During the feeding experiment, fasting body weight was monitored every two weeks. All animals were in a good health. Feed intakes and refusals were recorded weekly. Formulation and chemical analysis according to AOA (1995) of ingredients and tested rations are presented in Tables $1 \& 2$.

\section{RESULTS}

Table 1: Experimental rations

\begin{tabular}{lccc}
\hline \multirow{2}{*}{ Ingredients } & \multicolumn{3}{c}{ Experimental rations } \\
\cline { 2 - 4 } & Ration 1 & Ration 2 & Ration 3 \\
\hline Clover hay & 0.0 & 6.0 & 15.0 \\
\hline Barley grain & 83.0 & 77.0 & 68.0 \\
Soybean meal & 15.0 & 15.0 & 15.0 \\
Sodium chloride & 0.5 & 0.5 & 0.5 \\
Limestone (CaCo3) & 1.4 & 1.4 & 1.4 \\
Premix* & 0.1 & 0.1 & 0.1 \\
\hline
\end{tabular}

Premix consists per 3 kg consists of: Vit. A. 12000000 IU, Vit. D 2200000 IU, Vit. E 10 gm., Vit. k 29 gm., Copper, 10 gm., Zinc, 50 gm., Manganese, 55 gm., Iodine, 1 gm., Selenium, 0.1 gm., Carrier $\left(\mathrm{Ca} \mathrm{Co}_{3}\right) 3000 \mathrm{gm}$.

Table 2: Chemical composition of ingredients and experimental rations

\begin{tabular}{lcccccccc}
\hline \multirow{2}{*}{ Items } & \multirow{2}{*}{ DM } & \multicolumn{9}{c}{ DM basis \% } & GE* \\
\cline { 2 - 7 } & & OM & CP & EE & CF & NFE & ASH & MJ/Kg DM \\
\hline Barley grain & 89.55 & 97.92 & 11.71 & 2.15 & 3.71 & 80.35 & 2.08 & 18.46 \\
Soybean meal & 91.48 & 93.53 & 45.44 & 2.73 & 5.48 & 39.88 & 6.47 & 19.49 \\
Clover hay & 92.01 & 87.74 & 10.98 & 1.48 & 29.49 & 45.79 & 12.26 & 16.85 \\
Ration 1 & 90.34 & 94.91 & 11.88 & 1.36 & 6.09 & 75.25 & 5.09 & 17.73 \\
Ration 2 & 89.74 & 95.35 & 11.09 & 2.01 & 6.50 & 76.16 & 4.65 & 18.05 \\
Ration 3 & 90.52 & 94.38 & 11.98 & 2.20 & 8.44 & 71.76 & 5.62 & 17.92 \\
\hline
\end{tabular}

*Gross energy (GE) calculated according to MAFF (1975) using the following equation :

$\mathrm{GE} \mathrm{MJ} / \mathrm{kg} \mathrm{DM}=0.0226 \mathrm{CP}+0.0407 \mathrm{EE}+0.0192 \mathrm{CF}+0.0177 \mathrm{NFE}$

Where: CP, EE, CF and NFE are expressed as $\mathrm{gm} / \mathrm{kg} \mathrm{DM}$ 
Assiut Vet. Med. J. Vol. 54 No. 117 April 2008

Table 4: Feed intake and economic return of the experimental rations. 


\begin{tabular}{lccc}
\hline \multirow{2}{*}{ Items } & \multicolumn{3}{c}{ Treatment } \\
\cline { 2 - 4 } No. of lambs & 9 & I & 10 \\
Feed intake, kg. DM /h/d & 1.312 & 1.236 & 10 \\
Average daily gain, g & 0.187 & 0.183 & 0.208 \\
Feed efficiency, kg. DM/kg gain & 7.02 & 6.75 & 5.88 \\
Feed cost, LE/h/d & 0.890 & 0.823 & 0.793 \\
Feed cost, LE/kg gain* & 4.76 & 4.50 & 3.80 \\
\hline
\end{tabular}

* Based on the market price at that time for soybean meal, barely, hay, common salt and limestone were $1200,600,400,100$ and 60 LE./ton, respectively and premix $10.0 \mathrm{~L} . \mathrm{E} / \mathrm{kg}$ and price of $\mathrm{kg}$ live body weight is 13 L.E in 2002.

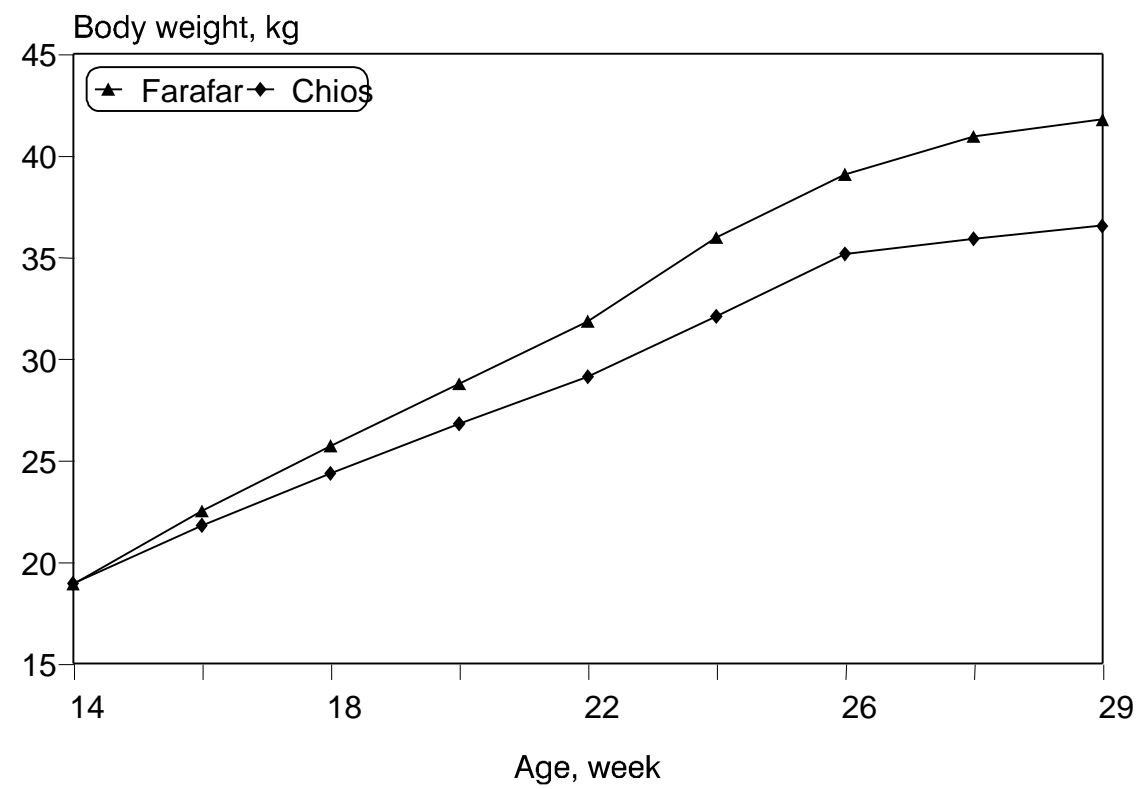

Fig.1. Changes of live body weight $(\mathrm{kg})$ of Farafra and Chios lambs through the fattening period. 


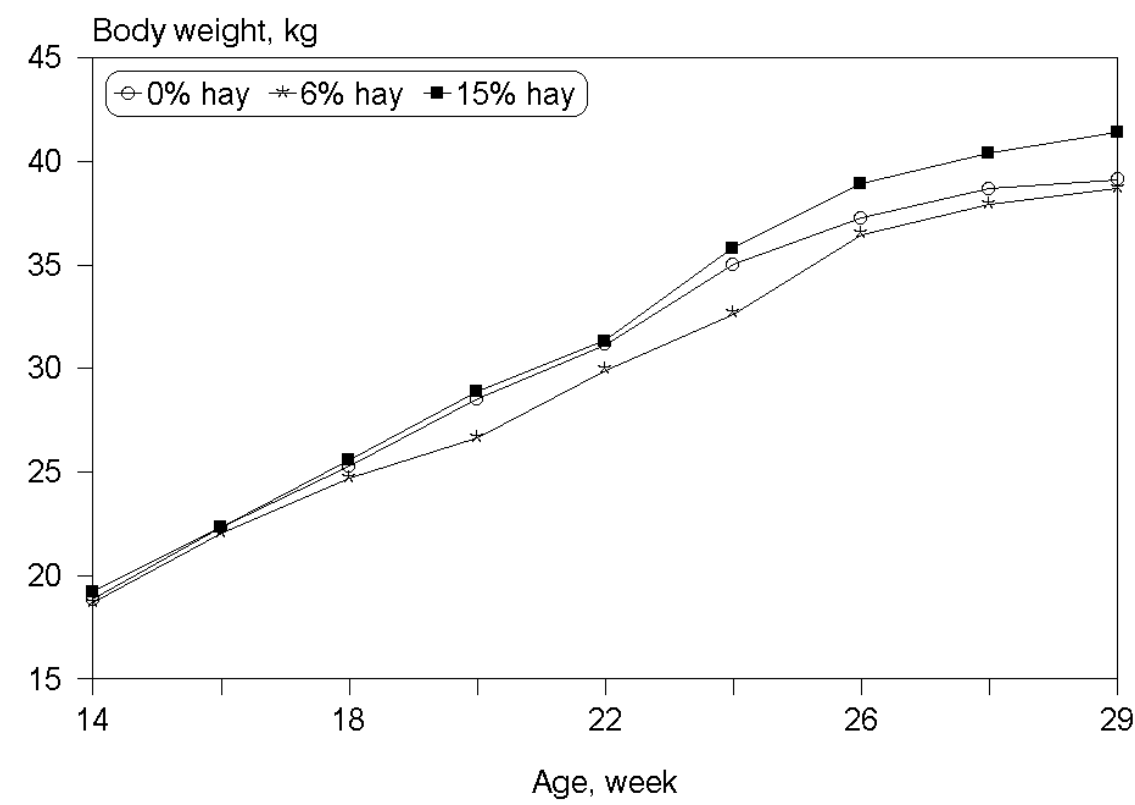

Fig. 2: Change of live body weig $(\mathrm{kg})$ through the fattening period with different feeding system

\section{DISCUSSION}

Breed effect: The least-squares means of body weight, total gain and daily gain of Farafra and Chios lambs during fattening period from weaning at 14 weeks of age to slaughter weight at 29 weeks of age are presented in Table (3) and Figure (1). Body weights of Farafra lambs were heavier than Chios at all ages (i.e 18, 22, 26 and 29 weeks of age). Averages body weight of Farafra lambs were 25.71, 31.84, 39.06 and $41.76 \mathrm{~kg}$, and for Chios lambs were $24.43,29.23,35.24$ and $36.57 \mathrm{~kg}$, respectively. These genotype differences were not significant except the final weight significant at 29 weeks $(\mathrm{P}<0.05)$ (Table, 3). So, daily gain values and total daily gain of Farafra lambs were higher than Chios lambs at all periods. Average daily gains were 243, 219, 258, and 128 g/day for periods from 14-18, 18-22, 22-26 and 26-29 weeks of age, respectively. Moreover, average total daily gain was $218 \mathrm{~g} / \mathrm{day}$ for Farafra lambs and $168 \mathrm{~g} /$ day for Chios lambs. All genotype differences in daily gain were significant $(\mathrm{P}<0.05)$ for periods from $14-18$ and 18 22 weeks, but were highly significant $(\mathrm{P}<0.01)$ for periods from $22-26$ and 26-29 weeks. Also, breed was of highly significant $(\mathrm{P}<0.01)$ effect on average total daily gain during fatting period (Table, 3 ). In this 
respect, Ali (1994) work on Ossimi and Chios, found that breed had significant differences $(\mathrm{P}<0.05)$ in final weight and total gain. The difference in average daily gain was not significant (160.0 g/day and $162.6 \mathrm{~g} /$ day) for Ossimi and Chios, respectively. While, El-Mahdy et al., (2000) working on Ossimi and $1 / 2$ Ossimi $\times 1 / 2$ Rahmani, found that the differences between body weights of each of initial and final weights, due to breed group effect were not significant. Macit et al. (2002) reported that the difference between Morkaraman and Tushin lambs groups in daily weight gain was significant.

Feeding system: Body weight and daily gain comparisons were made during the fattening period. Data represents the least-squares means of body weight, total gain, daily gain and average total daily gain for the different levels of hay. Table (3) and Figure (2) show changes of live body weight through the fattening period with different levels of hay $(0$, 6 and $15 \%$ ).

These data show that the third group which received the diet containing $15 \%$ hay, had the highest body weight at all ages, total gain, and average daily gain. However, the second group that received the 6\% hay containing diet had light body weight at all ages, total gain and average daily gain than the first group (control). Moreover, the third group had the highest average daily gain of $208 \mathrm{~g} / \mathrm{d}$ than the second and first group (control), $183 \mathrm{~g} / \mathrm{d}$ and $187 \mathrm{~g} / \mathrm{d}$, respectively, although the differences were not significant (Table, 3 ). These differences may be attributed to higher levels of hay supplementation that improved the growth performance or increased dry matter intake which attributed to their regulatory effect on dietary energy intake. According to Fimbres et al., (2002), when lambs were fed rations, particle size of forage was small enough so that physical fill was not the dominant factor in the regulation of intake.

Mohamed (1986) reported that Barki male lambs were affected by feeding system, they fed the animals on restricted feeding and hay ad lib. plus a daily intake of $2 \%$ of the average live body weight as a concentrate pelleted mixture. They reported that the average body weight, average total gain and average daily gain/head/day were 48.71 , $26.37 \mathrm{~kg}$ and $126 \mathrm{~g}$ and 50.06, 26.56 and $127 \mathrm{~g}$ for the group fed hay ad lib. and restricted fed group, respectively, but the differences were not significant. On the other hand, Marai et al., (1997) found that average daily gain in lambs fed all concentrate ration (245.05g) was higher than those fed ration based on concentrates plus roughages (118.049). However, Shehata (1997) reported that the average daily gain attained by 
local lambs groups was $225 \mathrm{~g} / \mathrm{h} / \mathrm{d}$, ranging from $145 \mathrm{~g} / \mathrm{h} / \mathrm{d}$ to $379 \mathrm{~g} / \mathrm{h} / \mathrm{d}$, when fed on full concentrate ration. While, Shalaby (2000) found that there were wide individual variations in average daily gain of Barki lambs fed on full concentrate ration, ranging from 207 to 278 g/head/day. El-Bedawy et al., (2004) observed that total gain and average daily gain were not significantly increased by $10 \%$ hay than in $30 \%$ hay (15.1 vs. $14.7 \mathrm{~kg})$ and (217 vs. $210 \mathrm{~g})$, respectively.

Feed intake and feed efficiency: Dry matter (DM) intake, efficiency of DM utilization (kilograms of dry matter/ kilograms live weight gain) and feed cost were calculated for different feeding systems (Table, 4). Amount of DM consumed averaged 1.312, 1.236 and $1.222 \mathrm{~kg} / \mathrm{head} /$ day for groups $0 \%, 6 \%$ and $15 \%$ hay, respectively. Lambs received 6 or $15 \%$ hay rations consumed less feed DM by 5.8 and $6.9 \%$, respectively. Results revealed that increasing the percentage of hay in the diets caused a slight depression in the amount of DM consumed in spite of the increased average daily gain. This depression of dry matter consumed may be attributed to the high fiber content $(8.44 \% \mathrm{CF})$ for $15 \%$ hay group compared to $(6.09 \%$ and $6.50 \% \mathrm{CF})$ for $6 \%$ hay and $0 \%$ hay groups. Cameron and Hogue (1968) found that lambs fed the low fiber high oil group gained significantly $(\mathrm{P}<0.05)$ less than other groups that consumed the medium and high fiber diets. The values of feed conversion (kg DM consumed/ kg gain) were $7.02,6.75$ and $5.88 \mathrm{~kg}$ $\mathrm{DM} / \mathrm{kg}$ gain for 0,6 and $15 \%$ hay groups. The most efficient value was observed for $15 \%$ hay group, while the lowest one was for control. Feed conversion ratio was enhanced gradually with increasing hay percentage in the ration. Silva and Portugal (1991) found that the composition of diet $(60 \%$ concentrate and $40 \%$ straw) had a greater proportion of concentrate and the protein to energy ratio was more balanced. Therefore, it may have allowed an increase of the microbial activity and degradation rate of carbohydrate components. They added that $40 \%$ roughage in the diet may allow a greater passage rate and thus a greater intake.

Mohamed (1986) reported that feed conversion ratio calculated on the basis of kilograms dry matter per kilograms of live weight gain was 8.5 and $9.3 \mathrm{~kg}$ gain for the hay ad lib and restricted fed groups, respectively, indicating a slight better feed efficiency of the hay ad lib group. While, Shehata (1997) found that feed conversion efficiency averaged 4.2: 1 (kg DM. feed per kg live body gain) and ranged among flocks from 6.2: 1 to 2.9: 1 during these ad lib feeding trials. Also, Shalaby (2000) reported that feed conversion ratio ranged from 4.024 to 
$5.455 \mathrm{~kg}$ DM per $\mathrm{kg}$ live body weight and averaged $4.364 \mathrm{~kg}$. ElBedawy et al., (2004) found that feed conversion ratio as $\mathrm{kg} \mathrm{DM} / \mathrm{kg}$ gain was 5.00 and 5.32 for $10 \%$ and $30 \%$ hay diets, respectively. However, hay level had no significant effect on fed conversion.

It is shown from Table (4) that the average of feed cost per kilograms gain was $4.76,4.50$ and $3.80 \mathrm{LE} / \mathrm{kg}$ gain for groups $0 \%$ (control), 6\% and $15 \%$ hay, respectively. Feed cost per kg gain from diets containing hay was reduced by about 5.5 and $20.2 \%$ for groups 6 and $15 \%$ hay, respectively, compared with the control. Such results may indicate that using higher hay percent than that applied in this experiment would be used, accordingly more profitability could be obtained. In the present study, inclusion of hay in the diets of growing lambs significantly improved average daily gain, feed conversion ratio. More important, it reduced feed costs and hence increased economic efficiency.

Gaber et al. (1998) showed that, when lambs fed on all concentrate ration, feed costs were $0.725 \mathrm{LE} / \mathrm{h} / \mathrm{d}$ and economic return was $2.9 \mathrm{LE} / \mathrm{kg}$ gain. However, Shalaby (2000) reported that cost of one kilogram weight gain averaged 3.6 LE and ranged from 3.078 to 4.790 LE for Barki Lambs on all concentrate rations.

It could be concluded that, Farafra ram lambs exhibited better performance on early fattening than Chios ram lambs in regard to final weight, average daily gain and total gain through fattening period. The use of concentrate with alfalfa hay level for early fattening did improve growth performance (body weight, average daily gain and total gain). Also, when hay level was increased to $15 \%$ with concentrate, it improved the feed conversion efficiency ( $\mathrm{kg} \mathrm{DM}$ consumed/kg gain) and reduced the feed cost per kilograms by about $20.2 \%$.

\section{REFERNCES}

Ali, I.A. (1994): Improvement of some Ossimi productive and reproductive traits through crossing with Chios breed of sheep. M.Sc. Thesis, Fac. of Agric., El-Minia Univ., Egypt.

AOAC. (1995): Official Methods of Analysis (16 ${ }^{\text {th }}$ Ed.), Association of Official Analytical Chemists, Washington, D. C., USA

Cameron, C.W. and Hogue, D.E. (1968): Effect of varying dietary corn oil and hay grain ratio on lambs growth and fat characteristics. J. Anim. Sci., 27: 533. 
El-Bedawy, T.M.; Salem, M.A.I.; Swasan Ahmed and Omer, H.A.A. (2004): Effect of dietary protected fat and roughage level on growth performance and carcass characteristics of growingfinishing lambs. Egyptian J. Anim. Prod., 41, Suppl., Issue, 237-252.

El-Mahdy, M.R.; Hamdia, H.; Khalil, M.H.M. Mahmoud and Gomaa, A.H.A. (2000): Study of Carcass quality in local sheep. Annals of Agric. Sc. Moshtohor. Vol. 38 (1): 101- 127.

Fimbres, H.G.; Hernandez-Vidal, J.F.; Picon-Rubio, J.R. Kawas and Lu, C.D. (2002): Productive performance and carcass characteristics of lambs fed finishing ration containing various forage levels. Small Rumin. Res. (43): 283-288.

Gaber, A.A.; El-Ayouty, S.A.; Zaki, A.A.; Abou-Ammou, F.F.; and ElGohary, E.S.I. (1998): Productive performance of lambs fed diets containing Nigella Sativa meal. Egyptian J. Nutrition and Feeds, 1 (2): 97- 107.

Macit, M.; Esenbuga, E. and Karaoglu, M. (2002): Growth performance and carcass characteristics of Awassi, Morkaraman and Tushin lambs grazed on pasture and supported with concentrate. Small Rumin. Res. 44: 241- 246.

MAFF. (1975): Ministry of Agriculture, Fisheries and food energy allowance and feeding systems for ruminants. Technical Bulletin, 33, HM 50.

Marai, I.F.M.; Bahgat, L.B.; Shalaby, T.H. and Abdel-Hafez, M.A. (1997): Fattening lambs on concentrates mixture diet alone without or with addition of natural clay under sub-tropical condition of Egypt. 1. Growth performance and behavior. Prod. International Conf. Animal, Poultry and Rabbit production and Health, 2- 4 September, Zagazig Univ., Zagazig, Egypt.

Mohamed, R.S. (1986): Effect of different levels of nutrition on the productive and reproductive performance of sheep. M. Sc. Thesis, Fac. of Agric., Al-Azhar Univ., Egypt.

Ponnampalam, E.N.; Dixon, R.M.; Hosking, B.J. and Egan, A.R. (2004): Intake, growth and carcass characteristics of lambs consuming low digestible hay and cereal grain. Anim. Feed Sci. and Tech. 114, 31- 41.

SAS, (1995): SAS User's guide: Statistics, SAS Institute Inc., Cary, NC.

Shalaby, T.H. (2000): Fattening of Barki lambs on all concentrate ration: on- farm in north western coastal zone of Egypt. Proc. Conf. Anim. Prod. in 21 the century, Sakha, 18- 20 April: 317-324. 
Shehata, E.I. (1997): Report on a new approach for more economic lambs. Egyptian J. Anim. Prod., 34 (2): 115-123.

Silva, J.S. and Portugal, A.V. (1991): Contribution to the study of body development in Merino precoce lambs, subject to two diets. Livestock Res. for Rural Develop. 3(2). June. 
Table 3: $\mathrm{LSM} \pm \mathrm{SE}$ of body weight and daily gain of growing lambs during the fattening period.

\begin{tabular}{|c|c|c|c|c|c|c|}
\hline \multirow[b]{2}{*}{ Items } & \multicolumn{2}{|c|}{ Breed } & \multicolumn{3}{|c|}{ Treatment } & \multirow[b]{2}{*}{ Overall mean } \\
\hline & Farafra & Chios & I & II & III & \\
\hline No. of lambs & 18 & 11 & 9 & 10 & 10 & 29 \\
\hline \multicolumn{7}{|l|}{ Body weight, $\mathrm{kg}$} \\
\hline at 14 weeks (Initial weight) & $18.91 \pm 1.00$ & $18.95 \pm 1.29$ & $18.97 \pm 1.49$ & $18.59 \pm 1.36$ & $19.24 \pm 1.36$ & $18.92 \pm 4.23$ \\
\hline at 18 weeks & $25.71 \pm 1.22$ & $24.43 \pm 1.57$ & $25.31 \pm 1.82$ & $24.45 \pm 1.67$ & $25.46 \pm 1.67$ & $25.19 \pm 5.16$ \\
\hline at 22 weeks & $31.84 \pm 1.38$ & $29.23 \pm 1.78$ & $31.07 \pm 2.07$ & $29.46 \pm 1.89$ & $31.07 \pm 1.89$ & $30.79 \pm 5.85$ \\
\hline at 26 weeks & $39.06 \pm 1.50$ & $35.24 \pm 1.94$ & $37.03 \pm 2.25$ & $35.81 \pm 2.05$ & $38.61 \pm 2.05$ & $37.58 \pm 6.36$ \\
\hline at 29 weeks (Final weight) & $41.76 \pm 1.48$ & $36.57 \pm 1.91$ & $38.60 \pm 2.22$ & $37.79 \pm 2.02$ & $41.10 \pm 2.02$ & $39.77 \pm 6.27$ \\
\hline Total gain, $\mathrm{kg}$ & $22.84 \pm 0.69$ & $17.62 \pm 0.90$ & $19.63 \pm 1.04$ & $19.20 \pm 0.95$ & $21.86 \pm 0.95$ & $20.86 \pm 2.94$ \\
\hline \multicolumn{7}{|l|}{ Daily gain, $\mathrm{kg}$} \\
\hline $14-18$ weeks & $0.243 \pm 0.01$ & $0.196 \pm 0.02$ & $0.227 \pm 0.02$ & $0.209 \pm 0.02$ & $0.222 \pm 0.02$ & $0.224 \pm 0.06$ \\
\hline $18-22$ weeks & $0.219 \pm 0.01$ & $0.171 \pm 0.02$ & $0.206 \pm 0.02$ & $0.179 \pm 0.02$ & $0.201 \pm 0.02$ & $0.200 \pm 0.05$ \\
\hline $22-26$ weeks & $0.258 \pm 0.01$ & $0.215 \pm 0.01$ & $0.213 \pm 0.01^{b}$ & $0.227 \pm 0.01^{\mathrm{ab}}$ & $0.270 \pm 0.01^{\mathrm{a}}$ & $0.242 \pm 0.04$ \\
\hline $26-29$ weeks & $0.128 \pm 0.01$ & $0.063 \pm 0.02$ & $0.075 \pm 0.02$ & $0.094 \pm 0.02$ & $0.118 \pm 0.02$ & $0.105 \pm 0.05$ \\
\hline Average daily gain, $\mathrm{kg}$ & $0.218 \pm 0.01$ & $0.168 \pm 0.01$ & $0.187 \pm 0.01$ & $0.183 \pm 0.01$ & $0.208 \pm 0.01$ & $0.199 \pm 0.03$ \\
\hline
\end{tabular}

$\mathrm{a}, \mathrm{b}$ : meame row having differ superscript different significantly $(\mathrm{p}<0.05)$ for the same category. 
